\title{
Organ Measurements Original Result Unit
}

National Cancer Institute

\section{Source}

National Cancer Institute. Organ Measurements Original Result Unit. NCI Thesaurus. Code C119888.

The unit of measure for the result of the organ measurement as originally received or collected. 